\title{
The Type and Number of Expeditions in the Franklin Search 1847-1859
}

\author{
W. GILLIES ROSS ${ }^{1}$
}

(Received 27 February 2001: accepted in revised form 14 June 2001)

\begin{abstract}
Forty-nine books and articles published during the last 140 years give two dozen different figures for the number of expeditions that participated in the search for Sir John Franklin (1847-59). The figures range widely, from 17 to more than 70. According to the classification of expeditions presented here, 20 search expeditions, 11 supply expeditions, and one relief expedition (a total of 32) were directly involved in the Arctic search, and four bi-purpose expeditions contributed in some way, making a total of 36. Three aborted search expeditions failed to reach the Arctic.
\end{abstract}

Key words: Franklin search, expeditions, number, classification

RÉSUMÉ. Quarante-neuf livres et articles publiés au cours des derniers 140 ans donnent une vingtaine de chiffres différents pour le nombre d'expéditions ayant participé à la recherche de sir John Franklin (1847-59). Les chiffres varient très largement, allant de 17 à plus de 70. Selon la classification des expéditions présentées ici, 20 expéditions de recherche, 11 expéditions de ravitaillement et une expédition de relève (total de 32) sont intervenues directement dans la recherche effectuée dans l'Arctique, et quatre autres expéditions à double mandat y ont également participé d'une manière ou d'une autre, ce qui fait un total de 36. Trois expéditions de recherche interrompues n'ont pas réussi à atteindre l'Arctique.

Mots clés: recherche de Franklin, expéditions, nombre, classification

Traduit pour la revue Arctic par Nésida Loyer.

\section{INTRODUCTION}

In view of the vast number of books and articles about the search for Sir John Franklin and the crews of HMS Erebus and Terror in the Arctic regions of North America, one would expect to see a strong level of agreement about the number of expeditions involved. Instead, the reader encounters a wide and confusing assortment of figures. A survey of more than 170 books and articles relating to Arctic exploration and the Franklin search turned up 49 publications that indicate the number of expeditions, and they give no fewer than 23 different figures, ranging from a low of 17 to a high of "more than seventy" - an astonishing difference. One wonders why so many contradictory statements have been published and which, if any, is correct. After all, the number of expeditions participating in the Franklin search is a fundamental piece of information.

The various figures are summarized in Table 1. Most of them represent unequivocal statements such as that of Skewes (1889:192), who wrote, "Some forty expeditions engaged in the search" or that of Delgado (1999:149), written more than a century later: "Between 1847 and 1859 thirty-two separate expeditions, both by land and by sea, searched the Arctic." A few authors, however, adopted time frames slightly narrower than the recognized Franklin Search Period (1847-59), and I have expanded these for inclusion in the table. G.B. Smith (1895:121), Randall (1907:[5]), and Wallace (1981:23), gave figures of 15, 15, and 22 respectively for the number of expeditions, but counted only up to 1854 . Adding the two subsequent expeditions of Anderson and Stewart, and McClintock results in figures of 17,17 , and 24 .

Blanket statements about the number of expeditions may appear to be authoritative, but unless they give the reader an indication of how they were derived it is impossible to assess their veracity. Far more revealing are lists that enumerate every expedition, give the names of their commanders and the ships involved, and sometimes provide additional useful information. By exposing the authors' research to scrutiny and showing what each author regarded as an expedition, such lists enable the reader to judge the reliability of the information and supplement it if feasible. Table 1, therefore, also includes totals that I compiled from lists of expeditions published by Richardson (1861), Simmonds (1875), Whymper (1875), Van Campen (1876), Nourse (1884), Baird (1949), Nanton (1970), and Holland (1994a).

Many other statements and lists are incomplete in some way and cannot be confidently expanded for inclusion in Table 1. The geographer Augustus Petermann (1853), for example, listed 14 expeditions, but only up to 1852 , and Smucker (1859:281), although publishing at the conclusion of the search, covered only its first two years. H.D. Trail (1896:381), one of Franklin's biographers, reported that "from first to last the number of search expeditions despatched from this country [Great Britain] and America amounted to as many as thirteen, without reckoning overland journeys." The humorist Stephen Leacock (1914:122),

${ }^{1}$ Department of Geography, Bishop's University, Lennoxville, Quebec J1M 1Z7, Canada; gilross @interlinx.qc.ca

(C) The Arctic Institute of North America 
TABLE 1. Published figures (1861-2000) for the total number of expeditions.

\begin{tabular}{|c|c|}
\hline Number & Source \\
\hline More than 70 & Pharand and Legault (1984:28) \\
\hline More than 50 & Berton (1988:150); Cookman (2000:205) \\
\hline 50 & Nickerson $(1996: 73-74)$ \\
\hline More than 40 & Nordenskjold and Mecking (1928:98); Woodcock (1970:686) \\
\hline 40 & $\begin{array}{l}\text { Richardson (1861:172 - 174); Skewes (1889:192); Maclean (1910:89); Stefansson (1938:59); Mirsky (1948:137); Kirwan (1959:166); } \\
\text { Ley (1962:34); Victor (1964:134); Wonders (1968:119); Keating (1970:83); Rasky (1977:67); Savours (1987:165, 1999:193); } \\
\text { McConnell (1991:244, 277) }\end{array}$ \\
\hline Almost 40 & Miller (1930:141) \\
\hline 39 & Kemp (1976:326) \\
\hline 38 & Kane (1916) \\
\hline 36 & Whymper (1875:121-123) \\
\hline 32 & Nanton (1970:256-258); Delgado (1999:149) \\
\hline 31 & Vaughan (1991:31) \\
\hline More than 30 & Bramwell (1998:15) \\
\hline 29 & Nourse $(1884: 33-37)$ \\
\hline 28 & Day (1986:445) \\
\hline 27 & Holland (1994a) \\
\hline 25 & Elder (1858:206) \\
\hline 24 & Wallace (1981:23) \\
\hline 23 & Van Campen (1876:238-241); Wonders (1981:8) \\
\hline 22 & Baird $(1949: 43-47)$ \\
\hline 21 & Simmonds (1875:294); Michael (c.1912?:133); Scott (1922:42); Gibson (1937:53); Wise (1973:24) \\
\hline More than 20 & Dunbar and Greenaway (1956:6); Loomis (1970:127); Holland (1994b:51); Leed (1998:199) \\
\hline 20 or more & Brendan (1929:273) \\
\hline 17 & G.B.Smith (1895:121); Randall (1907:[5]); Wallace (1981:23) \\
\hline
\end{tabular}

writing in a serious vein, stated that there had been 21 search expeditions between 1847 and 1851, but he did not include subsequent ones (his concluding date of 1851 may have been a typographical error for 1857). Leithauser (1955:332) listed 19 government expeditions up to 1854 but did not count private ones. Dodge (1961:x-x1) enumerated about 30 "voyages," but omitted overland ones. Vaughan (1994:155156) listed only what he considered "the most important of the Franklin search expeditions," totalling 17.

Authors who have described the expeditions of the Franklin Search Period as "numerous" (Wright, 1959:110), "multitudinous" (Baird, 1964:28), or "a series of expeditions" (Holmes c. 1897:84) consisting of "a whole series of ships" (Perry, 1883:378) or "dozens of ships" (MaxtoneGraham, 1988:4), or who have simply said "expedition after expedition was sent out" (Smith, 1885:90), have charted a safe course. One cannot dispute their statements, but they convey little information. We should know how many expeditions there were.

In this paper I will (a) suggest why such a diversity of opinions exists, (b) propose a scheme for classifying the various expeditions related to the search, and (c) attempt to arrive at an acceptable answer to the question, How many expeditions participated in the Franklin search?

\section{WHY ARE THERE CONFLICTING STATEMENTS?}

\section{Dates of the Search Period}

Two events identify 1847 as the year in which the search started. Not only did whaling captain William Penny make an effort to enter Lancaster Sound, hoping to sight cairns or other evidence of Franklin's passage, but the Admiralty initiated its searching plans by sending men and boats to Hudson Bay to be ready for an overland expedition down the Mackenzie River in the following summer, under Richardson and Rae. A few authors, however, not recognizing Penny's voyage as a searching expedition and not considering the preparation for the overland expedition as constituting part of the search, have taken the year 1848 as the starting year instead.

In 1854, Rae heard about the expedition's end from Inuit informants and obtained relics that had certainly come from Franklin's crew. Because Rae's news ended most of the speculation about the location of the missing men, this event could be considered the end of the search. The Admiralty did not send out any more search expeditions; Franklin and his men were struck off the Navy List; a memorial tablet was carried to Disko by Harstene's American expedition to be erected later on Beechey Island, the site of the first wintering by Franklin and his crews. Yet some doubts lingered about the veracity of Rae's hearsay evidence and the provenance of the relics he brought back. There was a keen desire, especially among families and friends of the missing explorers, to establish the exact location of the tragedy and to attempt to find records or other clues that would shed light on the circumstances. This resulted in what is usually regarded as the final search expedition, sponsored mainly by Lady Franklin and commanded by McClintock. The voyage of the Fox in 1857-59 led to the discovery of messages, relics, and bodies on King William Island. The fate of the expedition and the location of the disaster were now certainly known. Consequently, the year 1859 has almost universally been accepted as the end of the Franklin search. 
The "Franklin Search Period," therefore, spanned the years $1847-59$. During this period, virtually all the nonwhaling maritime voyages to the North American Arctic, as well as most of the overland voyages, had as their objective the discovery of Franklin's whereabouts, and his relief or rescue if necessary. (A few private expeditions went to the Arctic after 1859 in the hope of discovering additional records, relics, human remains, and possibly a few survivors living among the Inuit. Although the expeditions under Hall in 1860-62 and 1864-69 and that under Schwatka in 1878-80 have sometimes been called Franklin search expeditions, they are not so regarded in this paper because they occurred after the Franklin Search Period and the participants were aware that Franklin himself was dead.)

Despite general agreement on the dates of the search period, some of the authors represented in Table 1, including Miller (1930:141), Stefansson (1938:59), Mirsky (1948:137), and Kirwan (1959:166), stated that the search occupied only a decade, apparently beginning in 1847 . Whether they included McClintock's final expedition in the Fox, which departed in 1857, is not clear.

\section{Access to Documents}

Since there is no serious divergence of opinion about the time frame, the wide variety of figures for the number of expeditions must have some other cause. Is it possible that earlier scholars, working long before the convenience of air travel, photocopying, microreproduction, and the Internet, found it difficult or impossible to gain access to the necessary research documents? This does not appear to have been the case. The Arctic Blue Books (published parliamentary papers) and firsthand accounts of most of the expeditions were available during the search period itself, and the newspapers and magazines of the day were probably easier to consult then than they are now. John Brown (1858) made excellent use of such materials even before McClintock's final search voyage, and of course his own book (as well as ones by others) facilitated the work of subsequent writers. The number of publications on 19th-century exploration has increased prodigiously and shows no sign of abating. According to Alan Cooke (1985:14), the serious literature on the Franklin expeditions and search probably amounts to "well over a thousand monographs and articles." Today writers can draw upon all these resources.

Researchers who view the sheer number and volume of publications about the Franklin search as an impediment can turn to published lists of expeditions to facilitate the work. But most of the early lists are unreliable. Smucker (1859:281) included as one of the "relief and exploring vessels" Sir John Ross's small yacht Mary, which in fact was towed crewless all the way from Scotland to Barrow Strait in 1850 and left in the Arctic, yet he failed to list James Ross's two large, fully manned ships Enterprise and Investigator, which had wintered in the same region in
1848-49. Richardson (1861:172-174) included as separate "searching expeditions" six voyages by supply vessels, and he counted each of James Ross's two ships, each of Penny's two ships, each of De Haven's two ships, and each of Belcher's five ships (but for some reason only two of Austin's four ships) as separate expeditions. He also wrongly identified Robert Goodsir, surgeon of Penny's whaler Advice in 1849, as the ship's commander, a mistake apparently followed in turn by Whymper (1875:121), Van Campen (1876:239), Dodge (1961:x), and Nanton (1970:256). Simmonds (1875:294) counted Rae's two expeditions of 1850-51 and 1853-54 as one, but counted Pullen's one expedition of $1849-51$ as two. Van Campen $(1876: 238-241)$ gave incorrect dates for several expeditions, combined into one expedition two entirely separate ones on HMS North Star and the whaler Advice (incorrectly calling the latter Advance), omitted Austin's two steam vessels, transferred Belcher's two steamers to Inglefield's command, and stated that Belcher abandoned five vessels instead of four. In view of the errors and inconsistencies in early lists, it is hardly surprising that contradictory figures have resulted for the total number of expeditions.

Fortunately, some more reliable lists have become available. In 1949, P.D. Baird made the first serious attempt to provide a convenient research tool. His annotated list, entitled "Expeditions to the Canadian Arctic," identified the aims and the results of each expedition from Norse times up to 1918, gave brief summaries, and noted relevant publications (Baird, 1949). Thirty years later, Alan Cooke and Clive Holland carried Baird's concept much farther, producing a thorough and reliable reference work containing expeditions and important events during the period from 500 to 1920, with references and crew lists (Cooke and Holland, 1978). Holland (1994a) subsequently expanded the geographical coverage of this work to include the entire circumpolar Arctic. The invaluable compendiums of Cooke and Holland enable anyone to count up the number of Franklin search expeditions without the legwork formerly required. Yet the contradictions persist: three books published in the years 1999 and 2000 give figures of 32, 40, and more than 50 .

\section{Perpetuation of Error}

If the root of the contradictions is not disagreement about the duration of the search period, or difficulties of access to necessary documents, then what is? Perhaps the tendency to accept without question statements that have been published before is partly to blame. A writer intending to impress the reader with the extraordinary extent of the searching effort may not be willing to sacrifice valuable time in arriving at his own figure if someone else has already done the arithmetic. Many other vital aspects of his topic demand his attention, so he is content to adopt the conclusion of another writer and get on with his work. If he encounters conflicting statements, he probably selects the statement of the more reputable author. 
More than a third of the writers referred to in Table 1 gave the figure of 40 expeditions. The earliest to do so may have been Sir John Richardson, in his book The Polar Regions (1861). The conclusion of such a man-renowned for his achievements in exploration, science, and writing-was unlikely to be refuted without good reason. Three decades later, Skewes (1889) gave the same figure, and Miller (1930) repeated it four decades after that. Several years later, the well-known Arctic explorer and authority Vilhjalmur Stefansson (1938) added to its credibility, and then another widely read author, Jeanette Mirsky (1948), reproduced it in a book for which Stefansson wrote the foreword. The figure 40 appeared again a decade later in a book by L.P. Kirwan (1959), director of the Royal Geographical Society. Most recently it has occurred in a book by Ann Savours (1999), whose career has been connected with institutions such as the Scott Polar Research Institute, the Royal Geographical Society, and the National Maritime Museum. Each reaffirmation of the figure by a reputable or well-connected person, or inclusion in a book with wide distribution, has reinforced its solidity and increased the chances that it will appear again in the future.

\section{Lack of Agreement on What Constitutes an Expedition}

While chatting with an Arctic scientist, I remarked on the surprising lack of agreement among writers about the number of search expeditions. "But what do they mean by an expedition?" he asked, striking right to the heart of the matter. I could not enlighten him, because the writers whose figures are summarized in Table 1 have not defined their terms. The word is so common that they probably felt it unnecessary to provide a definition. Yet, the multiplicity of figures given for the total number of expeditions suggests that there has not been unanimity on the term's meaning, and even a cursory examination of some of the statements and lists reveals contradictory and inappropriate interpretations of the word.

\section{THE NATURE OF AN EXPEDITION}

\section{Definition of the Term}

The term "expedition" is broad and imprecise. According to The Oxford English Dictionary, 2nd edition (Simpson and Weiner, 1989), an expedition can be (a) "a sending or setting forth with martial intentions; a warlike enterprise"; or (b) "a journey, voyage, or excursion made for some definite purpose"; or (c) "a body of persons, also a fleet, etc., sent out for a warlike or other definite purpose."

Although Arctic discovery and search expeditions lacked "martial intentions," they could in a sense be considered "warlike." Not only were many of them carried out by naval men on naval ships, but they were usually described later, both by participants and by other writers, in terms of a confrontation between civilized man and a hostile environment. Nature, with its extremes of cold, its chilling winds sweeping unobstructed over the open tundra spaces, and its waterways filled with shifting, rock-hard ice, was regarded as the enemy. If an expedition attained its objective, or even if it failed in its purpose but managed to return safely, it was seen to have conquered the foe, Nature. The metaphor of struggle and victory (or sometimes defeat) is reflected in the titles of many books about the polar regions, which contain terms like "conquest" (Randall, 1907; Ingersoll, c. 1907; Mikkelsen, 1909; Bryce, 1910; Marshall, 1913; Judd, c. 1917; Laut, 1918; Byrd, 1930; Hayes, 1934; Heimbinder, 1934; Owen, 1952; Dolan, 1961; Victor, 1964; Neatby, 1966), "seige" (Mill, 1905; Bryce, 1910), "battleground" (Dolan, 1961), and "attack" (Weber and Malakhov, 1996).

There is no question that Arctic expeditions were voyages "made for some definite purpose" (would any voyage be otherwise?), and it seems self-evident that they included "a body of persons." (If a "body" means an aggregate of persons, then a solo voyage for a definite purpose would not count as an expedition, but this is a moot point. Although several solo voyages have been made through the Northwest Passage in recent years for sport and adventure, none were made in search of Franklin in 1847-59.) Finally, an expedition could certainly consist of a "fleet," that is to say a group of ships operating together in a "definite purpose." Inherent in the word "fleet" is the concept of unified command. A fleet has a commander.

Although not explicitly stated in the dictionary, it seems clear that an expedition could travel by land or by sea, or conceivably beneath or above their surfaces. Neither submarines nor aircraft were invented early enough for the Franklin search, however, and manned balloons, although often recommended during the search, were never actually employed.

\section{Ships Comprising an Expedition}

A troublesome problem is to decide how many ships were included in a particular expedition. Take, for example, Franklin's attempt to traverse the Northwest Passage in 1845. The expedition is always said to have consisted of two ships, the Erebus and the Terror. But one could make a very good case for including the transport Baretto Junior (sometimes spelled Barretto), which carried essential supplies as far as the Whale Fish Islands in Disko Bay, Greenland, and then transferred them to the discovery vessels. The transport was a vital part of the enterprise, enabling the Erebus and Terror to be topped up with supplies (replacing food, and possibly coal, consumed on the transatlantic part of their mission). One could object that the Baretto Junior did not accompany them all the way. She turned for home $1000 \mathrm{~km}$ short of Lancaster Sound, the entrance to the Northwest Passage. On the other hand, she did travel to the Arctic, reaching a latitude of almost $70^{\circ} \mathrm{N}$ in Baffin Bay. 
If one does not consider that the Baretto Junior was part of Franklin's expedition, then her voyage could be regarded as a separate expedition. This is the approach used by Holland (1994a:222), who calls the Baretto Junior's voyage a "naval supply expedition" that assisted Franklin's Northwest Passage expedition. (But the transports Emma Eugenia and Diligence, which sailed to Disko Bay with Austin and Inglefield respectively in 1850 and 1853, are not similarly listed.)

Several towing vessels also assisted Franklin's two discovery ships. HMS Rattler, a steam frigate, towed the Erebus and the Terror out of the Thames and most of the way through the North Sea to the Orkney Islands. The steam vessel Monkey towed the Baretto Junior from the Thames northward as far as Aberdeen. Finally, there was the steam vessel Blazer, initially sent after Franklin with a message, but then detained to help with the towing as far as Orkney. HMS Erebus and Terror were bluff-bowed, slow-sailing bomb vessels-so slow that even their bulky transport Baretto Junior had to reduce sail to avoid outdistancing them. Although both ships were equipped with locomotive engines and screw propellers, Franklin did not waste his precious coal in the North Sea and appears to have refrained from using any on the transatlantic passage because he wanted to save it for ice navigation. (On 10 July, as his ships prepared to set off from the Whale Fish Islands on the west coast of Greenland, Commander Fitzjames (1852) wrote, "We shall start with three years provisions and the Engine" [his italics].) Without the assistance of the steam-powered towing ships, the Erebus and the Terror would certainly have made a very slow passage around Scotland to the Atlantic, which, in view of their late departure from the Thames, would undoubtedly have jeopardized the success of the expedition even further. Like the transport, the towing vessels (or "steamaids," as Belcher called such ships in 1852) might be considered an important part of the expedition. If so, Franklin's expedition could be said to have comprised not two ships but six: two discovery vessels, one transport, and three steam-aids.

\section{The Hierarchy of Command}

An expedition that includes more than one ship has an overall commander at its head. The chain of command was often complex, however. Take Belcher's search expedition of $1852-54$ as an example. The Admiralty sent four ships (two sailing ships and two steam auxiliary ships), accompanied by one sailing ship to serve as a base, supply depot, and refuge in case of trouble. The four searching ships were organized in pairs, each sailing ship accompanied by an auxiliary steam tender to assist in towing when necessary. Each ship had a commanding officer, but the commanders of the sailing ships were senior to those of the steamers so that they could direct the operations of their respective tenders. All five ships were under the overall command of Belcher, and they sailed in convoy.
The Admiralty, Belcher himself, and the newspapers of the day called this one expedition, but the compilations by Cooke and Holland (1978) and Holland (1994a) list it as three, treating Assistance and the steamer Pioneer as one expedition, Resolute and the steamer Intrepid as a second, and the base vessel North Star as a third. The reason for doing so is given by Holland (1994a:242). Referring to the Resolute and Intrepid (both under Kellett's authority), he writes: "These two ships were under the general command of Sir Edward Belcher...but for the most part they were stationed so far from Belcher's own ships that they acted as an independent expedition." While it is useful to point out that part of Belcher's expedition operated more or less independently from its other parts, it seems awkward to suggest that one expedition was made up of three expeditions, and if one is attempting to arrive at a total number of search expeditions, such double counting exaggerates the figure. Belcher's squadron or fleet of five ships should be considered as one Franklin search expedition whose three component parts—or "divisions," as they were termed by Baird (1949:10)—operated in different geographical areas. Despite their distance from each other, the three divisions remained under the overall command of Belcher, as shown by his order to abandon four of the ships.

Whether a particular vessel should be regarded as part of an expedition or as a separate expedition should be indicated in the orders of the commanders involved. The decision on this point will, of course, affect the figure for the total number of expeditions.

A few of the authors represented in Table 1, such as Dodge (1961) and Van Campen (1876), used the term "voyage" either instead of, or in addition to, the word "expedition." Obviously, any ship performs a voyage when it travels from place to place, whether as part of an expedition or not. But an expedition is something more than a mere voyage. The term suggests a lofty objective, an enterprise beyond the routine, greater challenges to be faced, more sophisticated organization, and perhaps cooperation with other ships or land parties in a common purpose. Considering the very difficult problem of locating Franklin in a vast uncharted wilderness and the severe environmental hazards that restricted all human activities in the Arctic, the term "expedition" seems more appropriate, and it is used throughout this paper.

\section{THE FRANKLIN SEARCH: APPROACHES TO A CLASSIFICATION}

Most of the writers represented in Table 1 did not distinguish between expeditions that had different functions. They usually mentioned search expeditions, expeditions sent out to find Franklin, expeditions engaged in the search, and so on. In most cases it is impossible to know which particular expeditions they had counted. Those who produced lists, however, revealed more about their method, and they revealed some inconsistencies. For example, 
although Richardson (1861:172-174) included supply expeditions under the blanket term "searching expeditions," Van Campen (1876:238-241) omitted supply expeditions altogether. The idea of including all expeditions, but at the same time differentiating between those whose purpose was to search and those whose function was to carry supplies to ships already in the Arctic, appears to have originated with Nourse (1884:34-37). Baird (1949) continued this approach by listing the objective of each expedition. The comprehensive compilation by Cooke and Holland (1978) went much farther, indicating the primary function of each expedition with terms such as "Franklin search expedition," "exploring expedition," "supply voyage," "depot-laying journey," and so on. Their work fully demonstrated the usefulness of categorizing expeditions according to their function. In reprinting the list in his expanded version, Holland (1994a) made a few alterations in terminology. The present paper, building upon these solid foundations, attempts to establish a clear and inclusive classification of all the expeditions that contributed to the Franklin Search.

\section{The Searchers}

The primary objective of the enterprise that Stefansson (1938:59) called "the greatest humanitarian effort of its kind in history" was to discover where Franklin's ships and men were located and provide assistance if necessary. The searching strategy designed by the British Admiralty embodied the principle of giving searching parties adequate time in which to operate. It recognized that they would be severely curtailed by the severe Arctic climate, that they would have to take maximum advantage of the very limited periods during which travel by sea or by land was feasible, and that they might have to stay out for two years or more. Therefore, nothing should detract from their objective: if they ran low on supplies, more would be sent; if they required assistance, it would be provided; but they must direct all their efforts towards finding Franklin. These vanguards of the Franklin Search are referred to here as "search expeditions." However, one must recognize that these expeditions sometimes included support ships.

\section{Transports and Towing Vessels}

Although the example of Franklin's expedition above shows that both transports and towing vessels could perform useful service, and could therefore be reasonably considered either as part of an expedition or even as expeditions in their own right, it is imperative to recognize different degrees of relevance to the Arctic mission. HMS Erebus and Terror, the two ships ordered to traverse the Northwest Passage, were essential to achieve the objective and were therefore of far greater importance than any support vessels. To assess the relative importance of the transport and the steam-aids would be highly subjective, but it is clear that in a geographic sense the steam-aids were less significant because they did not steam much beyond the Orkney Islands-nowhere near the Arctic region in which the most challenging part of the mission was to be undertaken. They assisted the discovery ships and the transport in the early stages but were not really part of the expedition.

In this paper any transport, towing vessel, or other supporting ship that reached the Arctic is considered to be part of the main search expedition with which it was associated. According to Köppen's classification of climates, the Arctic is the region northwards of the warmestmonth isotherm of $10^{\circ} \mathrm{C}\left(50^{\circ} \mathrm{F}\right)$ (Strahler 1966:226). But temperatures were imperfectly recorded in the 19th century, isotherms are difficult to establish for maritime areas, and climate has changed over time. In the context of the Franklin search, I suggest an arbitrary (but simpler) demarcation of the Arctic maritime regions: it includes all the area between Greenland and Canada (north of the Strait of Belle Isle) and extends westward to the Bering Sea, where its southern boundary is the Aleutian Islands.

Applying this geographical criterion, no towing vessels count as part of a search expedition because none went as far as the Arctic. But it is worth noting that a few of them got close. In 1850, the Times (23 April) reported that Austin's transport "Maria Eugene" (by which it meant Emma Eugenia) would be towed by the steamer Lightning to a position 600 miles $(960 \mathrm{~km})$ west of Stromness, "close to the border of the ice." Similarly, in 1852 Belcher's steam-aids HMS Basilisk and Desperate (described as "reserve war steamers") were ordered to tow his sailing ships westward to $20^{\circ} \mathrm{W}$-a position south of Iceland. They actually dropped their tows the day before Belcher passed Cape Farewell, the southernmost point of Greenland (Belcher, 1855 [1]:24, 30).

\section{Supplying Expeditions in the Field}

Not all search expeditions were self-sufficient, and those that stayed out more than one winter usually required resupply. In 1853, HMS Phoenix and Breadalbane carried supplies to Lancaster Sound for Belcher's ships, accompanied as far as Disko Bay by the store ship Diligence. Inglefield was in overall command. Did this constitute one expedition, or two, or three? Was it-or were they-part of Belcher's expedition, or separate? If separate, should it-or they-be called search expeditions or supply expeditions? In the following year, the Phoenix and Talbot sailed to Lancaster Sound with more supplies for Belcher, again under the overall command of Inglefield. Depending on one's definitions, the number of expeditions could be as low as one (encompassing all the ships with Belcher at the time of sailing plus those that brought supplies in subsequent seasons), or as high as 10 (each ship-voyage considered as an expedition in itself).

As these resupply ships sailed to the Arctic a year or two after Belcher's original squadron, under independent 
command, they are here recognized as two separate expeditions, consisting of three ships in 1853 and two in 1854, whose object was to supply Belcher's expedition. While this is the approach used in the compilations by Cooke and Holland, they use the term "supply voyage." The term "supply expedition" seems preferable and is used in this paper. And whereas Cooke and Holland omit the transport Diligence, she is included here as part of Inglefield's supply expedition because she meets the criterion of reaching the Arctic region.

\section{Searching for the Searchers}

Ships that were sent into the Arctic to search for other Franklin search expeditions, and to assist or rescue them if necessary, deserve a special category. In 1855, Hartstene was in overall command of the Release and the Arctic, two American vessels that sailed to Baffin Bay to find Kane's Advance, which had departed two years earlier to look for Franklin. It seems reasonable to identify Hartstene's expedition as one two-ship "relief expedition," separate in time from that of Kane and sent for a different purpose, as in Cooke and Holland (1978). (Although the western division of Belcher's expedition was supposed to look for and assist Collinson and McClure, who had entered the Arctic islands by way of the Bering Strait, the primary objective of Belcher's expedition was to find Franklin, so it has been classified as a search, rather than a relief, expedition.)

\section{Ships Remaining on Station}

For six consecutive years (1848-54), HMS Plover was stationed in the Bering Strait region to provide backup for active searching ships and a refuge for any parties emerging from the Northwest Passage. Although the Plover spent most of her time waiting for Franklin to arrive rather than actively looking for him among the Arctic islands, she did examine parts of the Alaskan and Siberian coasts of the Bering Sea, and she was the starting point from which boat parties were dispatched eastward along the north Alaskan coast. She should therefore be considered a search expedition. As the ship was commanded by Moore during the first four years and by Maguire during the next two (there were some crew changes as well), Cooke and Holland (1978) call it two expeditions, but here it is regarded as only one expedition because the ship remained in Alaska for the entire period without returning to Britain. (In the eastern Arctic, HMS North Star remained at Beechey Island from 1852 to 1854 , but as an integral part of Belcher's search expedition.)

\section{Travelling Parties}

Most of the actual searching accomplished by maritime expeditions was carried out by travelling parties that set out on foot or by boat from wintering ships. Such parties were not included in any published lists until 1978, when
Cooke and Holland carefully enumerated 75 such excursions, of which 46 were identified as "Franklin search expeditions" and the rest as "expeditions" (or sometimes "journeys") for depot-laying, despatch-carrying, relief, and so on. But to call some of them separate expeditions is inappropriate. The officers and men were detached from their icebound ships under orders drawn up by the various ships' commanders (not the Admiralty in London), and they returned to their vessels a few weeks or months later to resume their normal shipboard duties. They were not expeditions in the full sense of the term, but merely travelling parties attached to specific expeditions. Nonetheless, their extraordinary achievements are worthy of note, and the valuable work of summarizing them has been carried over into the subsequent work by Holland (1994a), in which the term "expedition" has been dropped.

One of these travelling parties was significantly different, however. The men commanded by Pullen left the Plover at Wainwright Inlet, Alaska, in 1849, travelled in two boats along the Arctic coast to the Mackenzie River, ascended the river, wintered in the interior, then returned to the delta and explored farther east. After returning to the Mackenzie River and wintering again, they made their way overland to Hudson Bay, and they reached England more than two years after departing from the Plover in Alaska. Since its members operated for so long on their own initiative, making their own arrangements for provisioning and transportation, covering so much ground, and never returning to their ship, this party deserves to be treated as a search expedition in itself, even though it originated from a ship already in the Arctic.

\section{Part-time Involvement in the Search}

How should one classify a ship that was initially engaged on a mission unconnected with the Franklin search, but became temporarily involved in it? HMS Herald provides an example. She was in the equatorial Pacific on a surveying assignment when orders were received to purchase provisions, sail to Alaska, and deliver them to HMS Plover. For the next three years, the Herald alternated winter surveying with summer supply voyages to Alaska. Although the Herald spent only part of each year in work associated with the Franklin search, her three summer trips were entirely devoted to the search, and should be recognized as supply expeditions. In the same category were other naval vessels that were detached from normal duties in the Pacific to act as supply expeditions to Alaska in summer-HMS Daedalus in 1851, Amphitrite in 1852 and 1853, and Trincomalee in 1854. Another supply expedition on HMS Rattlesnake was sent all the way from England in 1853. In 1849, the private yacht Nancy Dawson interrupted an intended circumnavigation for more than two months to assist the navy's searching activities in Alaska. This portion of her pleasure cruise, in which she accompanied Pullen's boats for $80 \mathrm{~km}$ past Point Barrow and established a depot on the coast, may be considered a 
search expedition because her activities were wholly directed to the search during that period.

\section{Searching as a Secondary Activity}

Different again were expeditions whose primary function was unrelated to the Franklin search, but which contributed to it in some significant way while performing their normal work. They are here called "bi-purpose expeditions." The first of these was Penny's 1847 whaling voyage on the Saint Andrew. Although adverse winds prevented Penny from making much progress up Lancaster Sound, his voyage constituted the first attempt to look for evidence of Franklin, and it should therefore be recognized. Two years later, Penny sailed the whaler Advice farther into the sound and deposited messages for Franklin on the Wollastan Islands, while Captain Parker on the whaler Truelove, sailing in company, landed coals and provisions for the missing men at Cape Hay. In Cooke and Holland (1978), these two voyages of 1849 are lumped together as one "whaling voyage and Franklin search," but the ships were registered in different ports, owned by different companies, and commanded by different masters. The two captains simply agreed informally, for convenience and security, to join company during their nine-day foray into Lancaster Sound. In this paper they are regarded as two separate bi-purpose expeditions.

In 1853, John Rae undertook on behalf of the Hudson's Bay Company to fill in geographical details of the poorly known mainland coast in the region of King William Island and the Boothia Peninsula. But after encountering the Inuit who provided him with authentic relics from Franklin and his men and told stories of their starvation, Rae attempted to follow up these indications of disaster. Because he uncovered the first real clues to the tragedy, it may be tempting to call this a Franklin search expedition, as many writers have done, but it is more accurately described by Cooke and Holland (1978) as an "exploring expedition and Franklin search," that is to say, a bipurpose expedition. The first shocking information about the catastrophe was thus revealed, not by a Franklin search expedition sent out by the Admiralty, the United States government, or private individuals, but by an expedition dispatched by a fur trading company to complete the mapping of the continental coast.

\section{Expeditions Cancelled on their Way to the Arctic}

Two maritime search expeditions departed for the Arctic but, owing to unforeseen circumstances, failed to reach it. Kennedy, the veteran commander of Lady Franklin's search expedition to the eastern Arctic on the Prince Albert in 1851, set off for the western Arctic on the Isabel a year later, again under her sponsorship. After rounding Cape Horn, he lost most of his crew to gold fever in Valparaiso, Chile, where the venture ended. Another attempt that resulted in failure, which was singular in having originated at nearly $40^{\circ} \mathrm{S}$ in Melbourne, Australia, was that of Snow on the small cutter Thomas in 1853. Storm damage and crew discontent ended this expedition halfway up the coast of the continent. A third search expedition, in which Pim attempted to travel overland through Siberia to the mouth of the Kolyma River in 1851-52, came to a premature halt in St. Petersburg when the Imperial government withheld its approval of the project, forcing Pim to abandon the scheme.

Because these expeditions failed to reach the Arctic (the first two did not even get to the Northern Hemisphere), they are not included in any of the published lists, and they do not appear to have been counted by any of the writers cited in Table 1. But they deserve to be recognized as part of the overall Franklin search effort because they were bona fide ventures, well intentioned, supported by private funds, and commanded by able and experienced men. Care must be taken, however, to avoid including them in the number of expeditions that actually undertook an Arctic search. In this paper they are called "aborted search expeditions."

\section{CLASSIFICATION OF EXPEDITIONS}

Bearing in mind the dictionary definitions discussed at the start and the approaches described above, I propose the following classification for expeditions during the Franklin Search Period:

(1) Search expedition. Purpose: to search for Franklin and provide help or rescue if necessary. A search expedition could be either (a) maritime, comprising the ship(s) actively involved in searching in the Arctic, any ship(s) that served as base, depot, or refuge, and any transport or towing vessel that accompanied the search ships as far as the Arctic (for example, Austin's expedition of 1850-51, which included four search ships and a transport that sailed to Disko Bay); (b) overland, a relatively small number of men traversing the interior by foot (perhaps hauling sledges or carts), or by boat, canoe, dog sled, or a combination of these methods (for example, Anderson and Stewart's expedition of 1855 down the Back River and back); or (c) coastal, a small expedition travelling primarily along coasts by boat (for example, Pullen's boat expedition of 1849-51 from Alaska to the Mackenzie River and beyond).

(Note that expeditions commonly referred to as "overland" normally reached the Arctic coast by river and sometimes travelled along parts of the coast in boats. They are termed "overland" not because their travel was restricted to land surfaces, but because they reached the coast by way of the continental interior rather than from the Atlantic or Pacific oceans. The most common route was down the Mackenzie River, sometimes diverging from Great Slave Lake or Great Bear Lake to cross drainage divides into smaller river basins draining to the Arctic coast. In the case of Barnard's 1850-51 overland expedition in Alaska, the travel was in the opposite direction, from the coast to the interior.) 
TABLE 2. Expeditions classified by type.

\begin{tabular}{|c|c|c|c|}
\hline $\begin{array}{l}\text { Search expeditions } \\
\text { Year }\end{array}$ & Leader(s) & Ships (or other) & Remarks \\
\hline $1847-49$ & Richardson \& Rae & overland & \\
\hline $1848-49$ & James Ross & $\begin{array}{l}\text { Enterprise (Ross) } \\
\text { Investigator (Bird) }\end{array}$ & Towing vessels: African, Fearless, Monkey, (none to Arctic) \\
\hline $1848-54$ & Moore; Maguire & Plover & \\
\hline 1849 & Shedden & Nancy Dawson & \\
\hline $1849-51$ & Pullen & coastal & \\
\hline 1850 & Forsyth & Prince Albert & \\
\hline $1850-51$ & Austin & $\begin{array}{l}\text { Resolute (Austin) } \\
\text { Assistance (Ommanney) } \\
\text { Intrepid (Cator) [steam] } \\
\text { Pioneer (Osborn) [steam] } \\
\text { Emma Eugenia } \text { [transport to Dis }\end{array}$ & Towing vessels: Advice, African, Dasher, Lightning, (none to Arctic) \\
\hline $1850-51$ & Penny & $\begin{array}{l}\text { Lady Franklin (Penny) } \\
\text { Sophia (Stewart) }\end{array}$ & \\
\hline $1850-51$ & John Ross & Felix & Towed un-manned Mary \\
\hline $1850-51$ & De Haven & $\begin{array}{l}\text { Advance (De Haven) } \\
\text { Rescue (Griffiths) }\end{array}$ & \\
\hline $1850-51$ & Rae & overland & \\
\hline $1850-51$ & Barnard & overland & \\
\hline $1850-54$ & McClure & Investigator & \\
\hline $1850-55$ & Collinson & Enterprise & \\
\hline $1851-52$ & Kennedy & Prince Albert & \\
\hline 1852 & Inglefield & Isabel $[$ steam $]$ & Towing vessel: Lightning \\
\hline $1852-54$ & Belcher & $\begin{array}{l}\text { Assistance (Richards) } \\
\text { Resolute (Kellett) } \\
\text { Pioneer (Osborn) [steam] } \\
\text { Intrepid (McClintock) [steam] } \\
\text { North Star (Pullen) }\end{array}$ & Towing vessels: African, Lightning, Monkey, Basilisk, Desperate, (none to Arctic) \\
\hline $1853-55$ & Kane & Advance & \\
\hline 1855 & Anderson \& Stewart & overland & \\
\hline $1857-59$ & McClintock & Fox & \\
\hline \multicolumn{4}{|l|}{ Supply expeditions } \\
\hline Year & Leader & Ship(s) & Supplies for: \\
\hline 1848 & Kellett & Herald & Moore \\
\hline 1849 & Kellett & Herald & Moore \\
\hline $1849-50$ & Saunders & North Star & James Ross \\
\hline 1850 & Kellett & Herald & Moore \\
\hline 1851 & Wellesley & Daedalus & Moore \\
\hline 1852 & Frederick & Amphitrite & Maguire \\
\hline 1853 & Inglefield & $\begin{array}{l}\text { Phoenix (Inglefield) [steam] } \\
\text { Breadalbane (Fawkner) } \\
\text { Diligence [transport to Disko] } \\
\text { (Elliott and Marryat) }\end{array}$ & Belcher \\
\hline 1853 & Frederick & Amphitrite & Maguire \\
\hline $1853-54$ & Trollope & Rattlesnake & Maguire \\
\hline 1854 & Houston & Trincomalee & Maguire \\
\hline 1854 & Inglefield & $\begin{array}{l}\text { Phoenix (Inglefield) [steam] } \\
\text { Talbot (Jenkins) }\end{array}$ & Belcher \\
\hline \multicolumn{4}{|l|}{ Relief expeditions } \\
\hline Year & Leader & Ship(s) & Relief of \\
\hline 1855 & Hartstene & $\begin{array}{l}\text { Release (Hartstene) } \\
\text { Arctic (Simms) [steam] }\end{array}$ & Kane \\
\hline \multicolumn{4}{|c|}{ Bi-purpose expeditions } \\
\hline Year & Leader & Ship(s) & Primary function \\
\hline $\begin{array}{l}1847 \\
1849 \\
1849 \\
1853-54\end{array}$ & $\begin{array}{l}\text { Penny } \\
\text { Penny } \\
\text { Parker } \\
\text { Rae }\end{array}$ & $\begin{array}{l}\text { Saint Andrew } \\
\text { Advice } \\
\text { Truelove } \\
\text { overland }\end{array}$ & $\begin{array}{l}\text { whaling } \\
\text { whaling } \\
\text { whaling } \\
\text { exploration }\end{array}$ \\
\hline \multicolumn{4}{|c|}{ Aborted search expeditions } \\
\hline Year & Leader & Ship(s) & Terminated in \\
\hline $1851-52$ & Pim & overland & Russia \\
\hline $1853-54$ & Kennedy & Isabel & Chile \\
\hline 1855 & Snow & Thomas & Australia \\
\hline
\end{tabular}


(2) Supply expedition. Purpose: to deliver additional stores to search expeditions already in the Arctic. An expedition consisted of one or more ships under the overall command of one person (for example, Inglefield's threeship expedition in 1853 for the resupply of Belcher's expedition).

(3) Relief expedition. Purpose: to locate and if necessary provide assistance to a Franklin search expedition thought to be in difficulty. An expedition comprised one or more ships under the overall command of one person (for example, Hartstene's two-ship expedition in 1855, which attempted to reach Kane's overdue search expedition).

(4) Bi-purpose expedition. Purpose: to engage primarily in some other activity (such as exploration or whaling) but at the same time to search for evidence of Franklin, leave messages, or cache supplies for survivors. A bipurpose expedition could be either maritime or overland (for example, Rae's overland expedition in 1853-54, which was sent out for exploration but uncovered evidence of the Franklin disaster while in the field).

(5) Aborted search expedition. Purpose: to search for Franklin. Such expeditions were intended to undertake a search but were cancelled on the way to the Arctic (for example, Kennedy's expedition in 1853-54, which terminated in Valparaiso owing to crew troubles).

\section{DISCUSSION}

Expeditions of the Franklin Search Period are listed in Table 2 by the five types given above, and a summary is presented in Table 3. According to this classification, 23 search expeditions attempted to find Franklin. Three of these were terminated en route, so only 20 actually reached the Arctic and undertook searches. They were supported or assisted by 11 supply expeditions and one relief expedition, making a total of 32 expeditions directly involved in the search. In addition, four bi-purpose expeditions, sent out for some other purpose, contributed to the search, so that altogether 36 expeditions were involved in the Franklin search (39 if the aborted search expeditions are included).

The popular figure of 40 expeditions (Table 1) is very close to the above total of 39, but the apparent agreement is largely coincidental. As I have suggested, the figure of 40 probably originated with Richardson (1861), whose conventions-including counting individual ships as separate expeditions-were quite different from those adopted in this paper. Neither he nor any of the other writers appear to have included the three maritime bi-purpose expeditions or the three aborted search expeditions. Furthermore, some of the writers restricted their count to expeditions whose specific function was to search (which in fact numbered only 20).

The wide variety of figures given in Table 1 is not altogether a result of error. It is as much a result of the writers' different ideas about what constitutes an expedition and about which expeditions or voyages deserve to be
TABLE 3. Summary of expeditions by type.

\begin{tabular}{lccccc}
\hline \hline Type & $\begin{array}{c}\text { Overland } \\
\text { or coastal }\end{array}$ & Maritime & $\begin{array}{c}\text { Total } \\
\text { number }\end{array}$ & $\begin{array}{c}\text { Ships } \\
\text { involved }\end{array}$ & $\begin{array}{c}\text { Ship- } \\
\text { winterings }\end{array}$ \\
\hline Search & 5 & 15 & 20 & 26 & 38 \\
Supply & - & 11 & 11 & 14 & 2 \\
Relief & - & 1 & 1 & 2 & - \\
Bi-purpose & 1 & 3 & 4 & 3 & - \\
Aborted & 1 & 2 & 3 & 2 & - \\
Totals & 7 & 32 & 39 & 47 & 40 \\
\hline \hline
\end{tabular}

counted as part of the Franklin search. In general, however, most of their statements are somewhat ambiguous on both these points.

The Franklin Search was primarily a maritime operation. Of the 36 expeditions of all types that actually reached the Arctic, only six were overland expeditions. This is hardly surprising, as Franklin's original expedition had gone by sea and had intended to traverse a large archipelago whose channels could best be reached by ship. Overland expeditions that intended to reach any of the Arctic islands had to either go by boat from the mainland coast or cross on ice surfaces before breakup, which imposed severe limitations. In addition, if search expeditions were prepared to rescue the crews of HMS Erebus and Terror, they had to carry enough extra food to sustain Franklin and his officers and men (numbering 129 when last heard of), something an overland expedition could never do. The impossibility of carrying bulky cargoes overland also meant that supply expeditions had to go by sea, as all of them did.

Altogether, the 32 maritime expeditions setting out on the Franklin Search included 47 ship voyages. These involved 32 different ships, 13 of which took part in more than one expedition. Only two of these voyages failed to reach the Arctic. There were 40 ship winterings in the Arctic, of which the majority (27) were in the east.

The various types of expeditions were not uniformly distributed in a geographic sense (Fig. 1). Search expeditions were more numerous in the eastern Arctic of North America, closest to the principal sending area in Britain and the secondary sending area in New England, and closest to Franklin's point of entrance into the Arctic archipelago. Not only were searches in the east more numerous, but they also involved a disproportionately large number of ships-five times as many as in the western Arctic. This was partly a result of the huge expeditions of Austin and Belcher, each of which comprised five ships. Supply expeditions, on the other hand, were more numerous in the western Arctic, owing to the necessity of supporting search ships that had already expended much of their provisions by the time they reached Alaska, and which had to operate a very long way from their home ports for several years. Most of the bi-purpose expeditions occurred in the eastern Arctic because the Admiralty and Lady Franklin offered rewards for Davis Strait whalers to participate in the search and they arranged for certain 


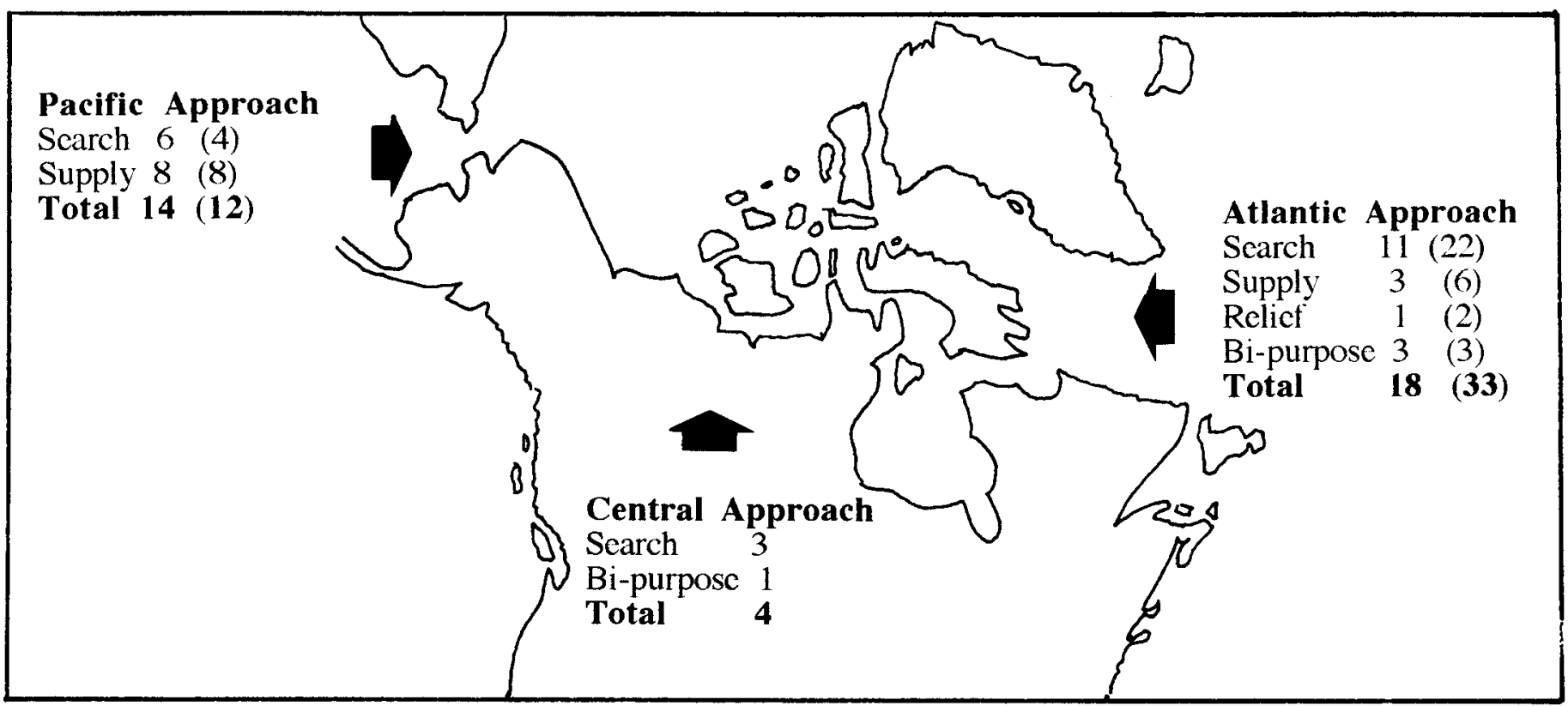

FIG. 1. Geographical distribution of the Franklin search effort. Number of expeditions by type, and number of ships involved (in parentheses), for the three main approaches to the Arctic search area. (Aborted expeditions are not included.)

whalers to lay down depots or messages. Attempts to motivate American whalers operating in Alaskan waters were unsuccessful, and no bi-purpose expeditions were mounted in the western Arctic.

Most of the expeditions set out from Britain, and two sailed from the East Coast of the United States. In addition, several originated in regions far from both these sending areas. Pullen, Shedden, and Barnard all initiated their search expeditions in Alaska, and several supply expeditions were diverted to Alaska from normal duties in the tropics. In the Canadian Northwest, Rae left his post at Fort Simpson in 1850 to undertake a search, and Anderson embarked with Stewart on a descent of the Great Fish (Back) River. Thus, although the Franklin Search depended mainly upon expeditions planned and equipped specifically for the purpose, it also utilized other resources when feasible, particularly the services of British ships deployed on far-flung missions, and those of Hudson's Bay Company posts and men in northern Canada.

Classification involves arbitrary decisions, and borderline cases are bound to occur. This paper should be considered as only one approach to answering the question, How many expeditions were involved in the Franklin search?

\section{ACKNOWLEDGEMENTS}

My sincere thanks to James Farfan, who helped me find obscure books about the Franklin Search, and also to Bill Barr, James Savelle, and Peter Schledermann, who provided useful comments on the text.

\section{REFERENCES}

BAIRD, P.D. 1949. Expeditions to the Canadian Arctic. The Beaver 279 (March):44-47; 280 (June):41-47; 280 (September): 44-48.

- 1964. The polar world. London: Longmans, Green.

BELCHER, E. 1855. The last of the arctic voyages.... 2 vols. London: Lovell Reeve.

BERTON, P. 1988. The arctic grail: The quest for the North West Passage and the North Pole, 1818-1909. Toronto: McClelland and Stewart.

BRAMWELL, M. 1998. Polar exploration: Journeys to the Arctic and Antarctic. London: Darling Kindersley.

BRENDAN, J.A. 1929. Great navigators \& discoverers. London: George G. Harrap.

BROWN, J. 1858. The North-west Passage and the plans for the search for Sir John Franklin. London: E. Stanford.

BRYCE, G. 1910. The siege and conquest of the North Pole. London: Gibbings.

BYRD, R.E. 1930. The conquest of Antarctica by air. National Geographic Magazine 58(2):127-227.

COOKE, A. 1985. A bibliographical introduction to Sir John Franklin's expeditions and the Franklin Search. In: Sutherland, P.D., ed. The Franklin era in Canadian Arctic history. Mercury Series, Archeological Survey of Canada Paper No. 131. Ottawa: National Museums of Canada. 12-20.

COOKE, A., and HOLLAND, C. 1978. The exploration of northern Canada 500 to 1929: A chronology. Toronto: Arctic History Press.

COOKMAN, S. 2000. Ice blink: The tragic fate of Sir John Franklin's lost polar expedition. New York: John Wiley.

DAY, A.E. 1986. Search for the Northwest Passage: An annotated bibliography. New York and London: Garland Publishing. 
DELGADO, J.P. 1999. Across the top of the world: The quest for the Northwest Passage. Vancouver and Toronto: Douglas \& McIntyre.

DODGE, E. 1961. Northwest by sea. New York: Oxford University Press.

DOLAN, E.F. 1961. White battleground: The conquest of the Arctic. New York: Dodd Mead.

DUNBAR, M., and GREENAWAY, K.R. 1956. Arctic Canada from the air. Ottawa: Defence Research Board.

ELDER, W. 1858. Biography of Elisha Kent Kane. Philadelphia: Childs \& Peterson and New York: Sheldon, Blakeman.

FITZJAMES, J. 1852. Letter to William Coningham, 10 July 1845. In: Arctic matters. Nautical Magazine 21: 195-201.

GIBSON, W. 1937. Sir John Franklin's last voyage. Beaver 268(1):44-75.

HAYES, J.G. 1934. The conquest of the North Pole. London: Thornton Butterworth.

HEIMBINDER, B.A. 1934. White conquest (An epic of Antarctica). New York: Privately printed.

HOLLAND, C. 1994a. Arctic development c. 500 B.C. to 1915: An encyclopedia. New York and London: Garland Publishing.

— 1994b. Farthest north: The quest for the North Pole. London: Robinson.

HOLMES, P. [c.1897]. The story of exploration and adventure in the frozen seas. Philadelphia: Henry Altemus.

INGERSOLL, E. [c.1907]. The conquest of the North. New York: C.S. Hammond.

JUDD, A. [c.1917]. The conquest of the poles and modern adventures in the world of ice. London: T.C. \& E.C. Jack.

KANE, E.K. 1916. Adrift in the arctic ice pack. From the history of the First U.S. Grinnell Expedition in search of Sir John Franklin. Edited by Horace Kephart. New York: Outing Publishing.

KEATING, B. 1970. The Northwest Passage from the Matthew to the Manhattan: 1497 to 1969. Chicago, New York, San Francisco: Rand McNally.

KEMP, P., ed. 1976. The Oxford companion to ships and the sea. London: Oxford University Press.

KIRWAN, L.P. 1959. The white road: A survey of polar exploration. London: Hollis \& Carter.

LAUT, A.C. 1918. The conquest of the great Northwest. Toronto: Musson.

LEACOCK, S. 1914. Adventures of the far North: A chronicle of the frozen seas. Toronto: Glasgow, Brook.

LEED, E. 1998. Shores of discovery: How expeditionaries have constructed the world. New York: Basic Books (Harper-Collins).

LEITHAUSER, J.G. 1955. Worlds beyond the horizon. New York: Alfred A Knopf.

LEY, W., ed. 1962. The Poles. New York: Time.

LOOMIS, C.C. 1970. Biography and the preservation of private papers. In: Friis, H.R., and Bale, S.G., Jr., eds. United States polar exploration. Athens, Ohio: Ohio University Press. 127133.

MACLEAN, J.K. 1910. Heroes of the polar sea: A record of exploration in the Arctic and Antarctic seas. London: W. \& R. Chambers.

MARSHALL, L., ed. 1913. The story of polar conquest. Privately printed.
MAXTONE-GRAHAM, J. 1988. Safe return doubtful: The heroic age of polar exploration. New York: Charles Scribners.

McCONNELL, A. 1991. The Arctic. In: Keay, J., ed. The Royal Geographical Society history of world exploration. New York: Mallard Press. 236-255.

MICHAEL, C.D. [c.1912]. 'Mid snow and ice. Stories of peril in polar seas. London: S.W. Partridge.

MIKKELSEN, E. 1909. Conquering the arctic ice. London: William Heinemann.

MILL, H.R. 1905. Siege of the South Pole. London.

MILLER, F.T. 1930. The world's great adventures: 1000 years of polar exploration. Chicago and Toronto: John C. Winston.

MIRSKY, J. 1948. To the Arctic! The story of northern exploration from earliest times to the present. New York: Alfred A. Knopf.

NANTON, P. 1970. Arctic breakthrough. London: William Kimber.

NEATBY, L.H. 1966. The conquest of the last frontier. Athens, Ohio: Ohio University Press.

NICKERSON, S. 1996. Disappearance: A map. A meditation on death and loss in the high latitudes. New York: Doubleday.

NORDENSKJOLD, O., and MECKING, L. 1928. The geography of the polar regions. New York: American Geographical Society.

NOURSE, J.E. 1884. American explorations in the ice zones. Boston: D. Lothrop.

OWEN, R. 1952. The conquest of the North and South Poles. New York: Random House.

PERRY, R. 1883. The Jeanette: Also a complete and authentic narrative encyclopedia of all voyages and expeditions to the North Polar regions. Cincinnati: W.E. Dibble.

PETERMANN, A. [1853]. Historical summary of the search for Sir John Franklin. Reprinted from Seeman's Narrative of the voyage of H.M.S. Herald. London: Privately printed.

PHARAND, D., and LEGAULT, L.H. 1984. The Northwest Passage: Arctic straits. (International Straits of the World, No. 7) Dordrecht, Boston, Lancaster: Martinus Nijhoff..

RANDALL, H. 1907. The conquest of the Northwest Passage: A treatise. Minneapolis: Murphy, Travis.

RASKY, F. 1977. The North Pole or bust. Toronto: McGraw-Hill Ryerson.

RICHARDSON, J. 1861. The Polar regions. Edinburgh: Adam and Charles Black.

SAVOURS, A. 1987. The British Admiralty and the Arctic, 17731876. In: Pole Nord 1983. Paris: Editions du CNRS.153-167. 1999. The search for the North West Passage. London: Chatham Publishing.

SCOTT, G.F. 1922. Daring deeds of polar explorers: True stories of the bravery, resource, endurance, and adventures of explorers at the poles. London: Seeley Service; and Philadelphia: Lippincott.

SIMMONDS, P.L. 1875. The arctic regions and polar discoveries during the nineteenth century.... London: George Routledge and Sons.

SIMPSON, J.A., and WEINER, E.S.C., eds. 1989. The Oxford English Dictionary. 2nd ed. Oxford: Clarendon Press.

SKEWES, J.H. 1889. Sir John Franklin. The true secret of the discovery of his fate: A 'revelation.' London: Bemrose \& Sons.

SMITH, C.C. 1885. Arctic explorations in the eighteenth and nineteenth centuries. In: Winsor, J., ed. Narrative and critical history of America. Boston \& New York: Houghton, Mifflin. 81-103. 
SMITH, G.B. 1895. Sir John Franklin and the romance of the North-West Passage. London: S.W. Partridge.

SMUCKER, S.M., ed. 1859. Arctic explorations and discoveries during the nineteenth century. New York: C.M. Saxton.

STEFANSSON, V. 1938. Unsolved mysteries of the Arctic. New York: Macmillan.

STRAHLER, A. 1966. Physical geography. New York: John Wiley. TRAILL, H.D. 1896. The life of Sir John Franklin, R.N. London: John Murray.

VAN CAMPEN, S.R. 1876. The Dutch in the Arctic seas. London: Trubner.

VAUGHAN, R. 1991. Northwest Greenland: A history. Orono, Maine: University of Maine Press.

Sutton.

VICTOR, P.-E. 1964. Man and the conquest of the poles. London: Hamish Hamilton.
WALLACE, H.N. 1981. Geographical explorations to 1880. In: Zaslow, M., ed. A century of Canada's Arctic islands 18801980. Ottawa: Royal Society of Canada. 15-32.

WEBER, R., and MALAKHOV, M. 1996. Polar attack: From Canada to the North Pole, and back. Toronto: McClelland and Stewart.

WHYMPER, F. 1875. Heroes of the Arctic and their adventures. London: Society for Promoting Christian Knowledge.

WISE, T. 1973. Polar exploration. London: Almark Publishing.

WONDERS, W.C. 1968. Search for Franklin. Canadian Geographical Journal 76(4):116-127.

- 1981. Unrolling the map of Canada's Arctic. In: Zaslow, M., ed. A century of Canada's Arctic islands 1880-1980. Ottawa: Royal Society of Canada. 1-14.

WOODCOCK, G. 1970. The search for Franklin. History Today 20(10):686-694.

WRIGHT, N. 1959. Quest for Franklin. London: Heinemann. 